\title{
Béb község kétnyelvü ragadványnévrendszere
}

1. Bevezető. Jelen írás célja bemutatni a közép-dunántúli Béb község ragadványnévrendszerét. A Veszprém megye Pápai járásában található település etnikailag és nyelvileg is homogén, német lakossága a második világháború közvetlen következményei miatt felbomlott, majd azóta folyamatosan cserélődik. Az 1940-1950-es évek megpróbáltatásai a német nyelv feladására késztették a lakosságot, a nyelvcsere egyetlen generáció alatt megtörtént: mára mindössze öt lakos beszéli vernakuláris nyelvváltozatként. Így az egykor generációkon át öröklődő, elsősorban német nyelvű ragadványnév-állomány mára kiveszett a nyelvhasználatból, és felváltotta egy frissen keletkezett, ritkán öröklődő, inkább említőnév funkciójú, elsősorban magyar nyelvű ragadványnév-állomány.

A tanulmány első részében kitérek a ragadványnév mibenlétét és funkcióit érintő legfontosabb kérdésekre, majd röviden bemutatom a település névanyagának nyelvi jellegét erösen befolyásoló történeti eseményeket. Ezután következik az általam gyüjtött névanyag elemzése olyan szempontok szerint, mint a névadás mögött álló motiváció, a ragadványnevek öröklődő volta és ennek módja, valamint ezeknek az adott névközösség kognitív folyamataira vonatkoztatható tanulságai.

2. A ragadványnév mibenléte és funkciója. A ragadványnév fogalmának megragadására BALÁZS JUDIT definícióját (1982: 8) tartom a legmegfelelőbbnek: „ragadványnévnek tekinthetünk minden olyan névelemet, amely egy közösség névhasználatában valamiféle funkcionális okból a megnevezett személyéhez tapadt, saját vezetéknevén és keresztnevén, illetőleg annak becéző változatain kívül elöfordul a megnevezésben, figyelmen kívül hagyva a név kialakulásának idejét, hangulati tartalmát, öröklődő voltát, névkapcsolatait stb." Ugyanakkor ragadványnevek és becenevek között nem mindig húzható éles határ. A becenév legfontosabb ismérve, hogy az egyén keresztnevéből keletkezik (vö. HAJDú 2003: 638), míg ragadványnevek keletkezhetnek bármilyen nyelvi jelből - így keresztnévből és becenévből is - vagy akár értelmetlen hangsorból, tulajdonképpen érvényre juttatva HAJDÚ (2003: 58) megállapítását: „minden nyelvi jel tulajdonnévvé válthat, amit alkotója vagy használója annak tekint". A becenevek és ragadványnevek létrejöttében gyakran azonos névalkotási módok müködnek, valamint a becenevek is hordozhatnak konnotációt, és képesek hangulati tartalmat, valamint a névadónak a névhez és a névviselőhöz füződő viszonyát közvetíteni. Emiatt vannak, akik e két névtípust egy skála két végpontján helyezik el (1. BAUKo 2009: 15-16). Különválasztásuk sok esetben igényli a megfelelö névkompetenciát, a névviselö család- és keresztnevének, valamint a névadás eredeti motivációjának az ismeretét (BAUKo 2009: 15).

A ragadványnevek egy részének létrejötte mögött az identifikálás, a más(ok)tól való megkülönböztetés áll motivációként. Hiszen a név addig képes tökéletesen identifikálni viselőjét, amíg csak egy személy viseli, de az olyan kis közösségekben, ahol kevés családnév létezik, és a keresztnévállományból is csak kevés elemet használnak, a zavaró poliszémia előhívja a megkülönböztető funkciójú név szükségességét (LöRINCZE 1951: 69, J. SoLTÉsz 
1979: 46). То́тн Katalin (1966: 95) emiatt a ragadványnevet a kéttagú név (családnév + keresztnév) kiegészítésével létrejött háromtagú név egyik tagjaként értelmezi. Ezzel szemben LÖRINCZE LAJOS (1951: 68-69) a családnév helyettesítőjének tekinti: öröklődése esetén már valódi családnévnek tekintendő, amely identifikálja az egyént, míg anyakönyvezett családneve olyannyira visszaszorulhat a hivatalos használatba, hogy ismeretlenné válik a névközösség számára (vö. BAUKo 2009: 17-18).

A megkülönböztető név adásának azonban nem szükségszerü feltétele a személynevek túlzott megterheltsége (1. ÖRDÖG 1973: 152). A névadásban elsősorban a névadó kognitív befolyása érvényesül az elnevezendő entitásnak az elnevező nézőpontjából történő fogalmi és szemantikai megkonstruálása alapján (HoFFMANN 2012: 12). Egyes ragadványnevek elsődleges funkciója - legalábbis keletkezésük idején - nem a megkülönböztetés, hanem a jellemzés: annak az igénynek a kielégítése, hogy valakit valamifajta jellemzőnek vélt tulajdonsága alapján identifikáljanak (BALÁzs 1982: 34). Emellett BAUKo (2009: 10) a névadás további lehetséges indítékának tekinti a közösség ragadványnévadó gyakorlatát: a ragadványnévadás egy bizonyos ponton hagyománnyá, divattá válhat, így akkor is tovább él, mikor már nincs valós szükség rá.

Mindezen motivációk egyúttal tükrözik a névadás társadalmi hátterét, vonatkozásait, és népismereti forrásul is szolgálhatnak (B. GERGELY 1977: 84).

3. A településtörténet mint a ragadványnévrendszer társadalmi-nyelvi háttere. Béb község nyelvi szempontból mindig is sajátos, ambivalens helyzetben volt, ugyanis három magyar település fogja közre: Ugod, Csót és Nagygyimót. A Béb mint tulajdonnév elöször 1270-ben bukkan fel egy oklevélben, mely a birtok felosztásáról szól Bébi Péter és fiai közt. A település a török hódítás során elpusztult, újratelepítése csak azután történt meg, hogy mint Ugod tartozéka a 17. században az Esterházy családhoz került (1. LÁszLó 2002: 35-49).

3.1. A lakosság nyelvi-etnikai eredete. A helyi német nyelvváltozat a középbajorral mutatja a legtöbb egyezést (HAPP 1915: 82). HAPP JózSEF a 20. század elején végzett dialektológiai vizsgálatai alapján az egykori óhazát valahol a középbajornak az északival érintkező részére, Nyugat-Csehország osztrák részére teszi (1915: 82-84). Természetesen nem lehet figyelmen kívül hagyni, hogy a Bécs környéki nyelvjárás presztízsének hatására a Dunántúli-középhegység területén egy többé-kevésbé egységes nyelvjárási régió alakult ki bajor-osztrák szupersztrátummal (1. KNIPF-KomLósi 2011: 111-116). Mégis HapP elméletét látszanak igazolni az általa gyüjtött olyan megnevezések, mint pẹm Jöži köhm Josef'cseh

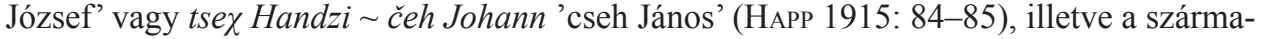
zás kérdésére adott válaszok: wīa sən taittš pẹ̄ma wir sind deutsch-böhmen 'német csehek vagyunk' (HAPP 1915: 84). Emellett valószínüsíthetö, hogy már a kezdetektöl érkeztek telepesek a Felvidékről is (1. LÁszLó 2002: 50), az ugodi plébánia anyakönyvében olvasható nevek is szláv eredetröl árulkodnak: Kucsera, Kušric, Pokorny, Prostovics, Leszkovics, Veilandics (HAPP 1905: 84). De szerepelnek ugyanitt francia eredetű családnevek is, mint a Massion és a La Croix (LÁszló 2002: 45, 49).

Annyi biztosan kijelenthető, hogy a Bébre érkező telepesek nem Svábföldről (Schwabenland) érkeztek: a település nyelvjárása olyan mértékben különbözik a svábtól, hogy a megértési nehézségek szinte el is lehetetlenítik az ott élőkkel való kommunikációt - erről saját 
tapasztalatai alapján számolt be egy adatközlőm. Ezért nem a sváb, hanem a német megnevezést használom a település német származású lakosaira és az általuk beszélt nyelvváltozatra.

3.2. A település nyelvi-nyelvhasználati viszonyai. 1741-1947 között a településen született gyermekek német nyelven szocializálódtak, és egészen az iskoláig egynyelvüek voltak, valamint anyanyelvüknek is csak a regionális nyelvváltozatát ismerték. A falu ugyan etnikailag és nyelvileg is homogén volt, de a lakosság kétnyelvű volt. ${ }^{1}$ A magyar nyelv használata azonban olyan formális kommunikációs helyzetekre korlátozódott, mint az iskola, a templom és a városi piac. (LÁszló 2002: 138-140.)

3.3. A második világháború következményei. A kollektíven bünösnek talált német lakosság kitelepítése 1947 novemberében érte el a települést, majd az év végén a csehszlovákmagyar lakosságcsere-egyezmény értelmében megérkeztek az első betelepítettek a Felvidékröl (LÁszLó 2002: 178-180), akik nemcsak nyelvükben, hanem kultúrájukban és vallásukban is eltértek a németektől. ${ }^{2}$ Mindez rendkívül ellentmondásos társadalmi-politikai légkört eredményezett, amelyet még inkább fokoztak a háború utáni nehéz életviszonyok és a vagyonuktól megfosztott, egymásra telepített németek nyomorúságos helyzete. Ettől kezdve már egyre több hátrány és támadás érte a falu németségét, az anyanyelv fokozatosan visszaszorult a familiáris használatba, és sokat vesztett presztízséböl.

A lingvicizmus valós következményeit a falu következő generációja szenvedte el: az 1950-1960-as évek szülöttei voltak az elsők, akiknek elsőként elsajátított, domináns nyelve a magyar lett. Adatközlőim beszámoltak róla, hogy egyes gyermekek még tanulták a nyelvjárást a nagyszüleiktől, azok halála után azonban ők is vagy passzív kétnyelvüvé váltak vagy teljesen elfelejtették a nyelvet, ahogy azt is, hogy valaha beszélték. Adatközlőim úgy vélték, a nyelv ilyen radikális cseréjét és beszélőinek ezzel szembeni tehetetlenségét a kor hozta magával. A 20. század második felétől újabb magyar anyanyelvü, magyar, később cigány etnikumú családok települtek a faluba, mintegy megteremtve a színtért a magyar nyelvü informális nyelvhasználat számára, és egyszersmind a magyar nyelv mindennapos használatának igényét a német eredetü lakosság részéről is.

\section{Béb ragadványnévanyaga}

4.1. A ragadványnevek forrása. A ragadványnevek a településen 2019 őszén végzett saját gyüjtésemből származnak. Adatközlőimet két csoportból választottam: 1. az 1920 1930-as években született, német anyanyelvü generációból, akik gyermekkorukat német egynyelvü környezetben, de már kétnyelvűként töltötték; 2. az 1950-1960-as években született, magyar anyanyelvü generációból, akik kétnyelvü környezetben, de már magyar

${ }^{1}$ A kétnyelvüségnek számos értelmezése, megközelítése és definíciója van a szakirodalomban. A vizsgálat során BARTHA CsILlÁét (2005: 40) értem kétnyelvűség alatt: „kétnyelvű az, aki a mindennapi érintkezései során két vagy több nyelvet kommunikatív, szociokulturális szükségleteinek megfelelően (szóban és/vagy írásban, illetőleg jelelt formában) rendszeresen használ”. A Sopron vármegyei birtokaikon lefolytatott boszorkányperek dokumentumai és Esterházy Miklós nádornak a német többségü Sopron tanácsával folytatott levelezése arról tanúskodik, hogy az Esterházy család elvárta minden földet kapó jobbágyától a magyar nyelv ismeretét (1. HAUBER megj. e.)

${ }^{2} \mathrm{~A}$ bébi lakosság római katolikus volt, míg a felvidéki magyarság református. 
egynyelvűként nőttek fel. Mindkét csoportból négy-négy adatközlöt kérdeztem meg. Kiválasztásuknál fontos és egyben korlátot is jelentő szempont volt, hogy olyanok legyenek, akik a gyermek- és ifjúkorukat a faluban töltötték, a ragadványnév-állományt aktívan használták, illetve - az 50-60-as évek generációja esetében - tevőlegesen részt is vettek a névanyag (ki)alakításában. A település lakosságának utóbbi évtizedekben történt jelentős cseréje miatt nehezen találtam megfelelő adatközlőket, a legidősebb generáció képviselői közül azonban csaknem mindenkit sikerült megkérdeznem.

A gyüjtés módszere ugyanaz volt a két csoport esetében. Előnyt jelentett, hogy magam is régóta a faluban élő családból származom, ez feloldotta az interjúk formális kommunikációs helyzetét, és felbátorította adatközlőimet a német nyelv használatára is. A második csoportban az adatközlőim előbb külön-külön, majd egy spontán összejövetel alkalmával közösen idézték fel a falu lakóinak ragadványneveit és a névadás motivációit. Az első csoport esetében adatközlöimet szintén külön-külön, a falu 1945. évi lakossági listája (1. RÁcz 2000) alapján kérdeztem ki.

4.2. A ragadványnevek rendszere a névadás indítéka szerint. A ragadványnevek rendszerezését alapvetően antropológiai szempontból szokás megközelíteni, vagyis a névadás mögött álló motivációk alapján (B. GERGELY 1977: 84). A ragadványnevek osztályozásában Tóth Katalin (1966) rendszerét követem, felhasználva egyúttal B. Gergely PirosKa módosítási javaslatait (1977), valamint bizonyos mértékig saját anyagomra is formálva - elsősorban elhagyva az üresen maradt, így irreleváns kategóriákat.

Míg То́тн megkülönböztette a névadásnak az egyén személyével kapcsolatos és azon kívül álló okait, én e két csoportot nem különböztettem meg egymástól, hiszen az általa az utóbbiba sorolt ragadványnevek - mint az elődök személyneveiből származó ragadványnevek és az ún. házi nevek (a ház tulajdonosának vagy a munkaadónak személynevéből származó ragadványnevek, 1. SzoTÁK szerk. 2017) - véleményem szerint ugyanúgy az elnevezetthez kötődő tulajdonságot ragadják meg, mint a testi-lelki tulajdonságokra és életkörülményekre utalók. Szintén összevontam az elődök nevéből származó ragadványnevek kategóriáit B. GERGELY osztályozásának mintájára, azonos megfontolásból (vö. B. GERGELY 1977: 85).

Ezenkívül, szintén követve B. GERGELYt, bővítettem saját osztályozási keretemet a névasszociációs indítékú és a puszta identifikációs és érzelmi indítékú ragadványnevek csoportjával. Ezeket a csoportokat már nem bontottam további alcsoportokra, ahogyan a külső-belső tulajdonságra utaló ragadványnevek csoportjainál is megtartottam TóTH osztályozását abból kifolyólag, hogy saját anyagom mérete nem kívánta meg B. Gergely osztályozásának részletességét. Viszont az életkörülményekre utaló ragadványnevek osztályába felvettem B. GERGELYtől a származásra, nemzetiségre utaló ragadványnevek csoportját.

Szólnom kell továbbá a komplex motivációjú ragadványnevek besorolási problémájáról. Ezek ugyanis nemcsak egy, hanem gyakran több különböző motivációból is kiindulhatnak, így pl. Pónicsődör (alacsony termete és szoknyavadász természete miatt). Emellett maga a névadó sem mindig tudja lekövetni saját kognitív folyamatait a névalkotás, névadás pillanatában, s a névben megőrzött esemény, szokás, elhangzott szó stb. tulajdonképpen egyben az elnevezett személyiségét is tükrözi (BALÁzs 1982: 35). Ezeket a neveket minden motivációs kategóriába besoroltam, ahová beletartoztak. Így lehetővé vált a település ragadványnévadásában szerepet játszó összes motiváció feltárása, valamint e motivációk közül a leginkább meghatározók kimutatása és mélyebb vizsgálata; egy külön, „bizonytalan” 
kategória felvétele ezt torzította volna. Emiatt az osztályozott nevek száma természetesen meghaladja a ragadványnevek tényleges számát. Az ide tartozó neveket*-gal jelöltem.

A továbbiakban külön osztályozásban közlöm az 1947-ig fennálló, valamint az 1947től napjainkig kialakult és használatban lévő ragadványnévrendszert. E szétválasztás oka a fentebb vázolt törés a település lakosságának életében, nyelvi és etnikai összetételében.

\subsection{A ragadványnevek rendszere 1947-ig}

4.3.1. A ragadványnevek funkciója. A település 20. század közepéig élő ragadványnévrendszerének az elsődleges funkciója az identifikáció volt. A ragadványneveket a teljes névközösség ismerte és használta: a családnév és keresztnév kettősének nem kiegészítői, hanem a családnevek helyettesítői, felváltói voltak. A névközösség ezzel a névvel identifikálta a családot, a valódi családnevet a legtöbb esetben nem is ismerték. A kialakulás motivációja egyértelmüen a családnevek megterheltsége volt: 1945-ben 480 före 44-féle családnév jutott. A legmegterheltebb a Mehringer családnév volt, amelyet 16 család viselt, utána a Novák 8, a Veilandics 6, majd a Stark, Veiland és Masszi családnevek 5-5 családdal.

Nem lehet véletlen tehát, hogy azok a családok viseltek ragadványnevet, amelyek a legkorábban érkeztek Bébre: 15 családnévhez 30 különböző ragadványnév rendelhetö. Ezek közül a Mehringer, a Veilandics és a Véber már szerepel az 1767-es úrbéri összeírásban is (Urb.), amely a település lakosságáról fennmaradt egyik legkorábbi forrásunk. E feltételezésem magyarázza azt is, hogyan lehetséges, hogy nem kaptak ragadványnevet az olyan családok, amelyeknek a családneve megterheltségben meghaladta más, ragadványnevet viselö családok családneveinek megterheltségét, valamint hogy a magas megterheltségü családnevet viselő famíliák között hogyan lehetnek olyanok, amelyek nem viselnek ragadványnevet. A Mehringer nevet viselö 16 család 10 különböző ragadványnéven osztozott, tehát 6 család esetében a zavaró poliszémia fennállt. Hasonlóképpen a 6 Veilandics nevet viselő családból csupán kettő viselt ragadványnevet. Szintén alátámasztja mindezt a magyar eredetü Bánhidi családnevet egyedül viselő család, amely a Tikə ragadványnevet kapta. A család eredetileg a német Eisler családnevet viselte, és csak a 20. század elején változtatták meg (MCsvA.). A településen további két család viselte az Eisler családnevet, mindkettő viselt ragadványnevet is. Szintén viselt ragadványnevet a Kisabonyi család, névváltoztatásukról azonban nincs hivatalos forrás.

Feltételezésem szerint a családnevet felváltó ragadványnév adása sokkal inkább volt jellemző a névközösség 20. századot megelőző életében. Így kaphattak ragadványnevet a legkorábban betelepülő családok, feloldva ezzel a családok növekedésével és osztódásával egyre inkább fellépő identifikációs zavarokat. E névadási gyakorlat azonban a 19. század második felére, illetve végére kifulladhatott, hiszen az addigra informálisan lezajlott névcsere folytán a formális családnév az új, elkülönítendő család esetében tökéletesen be tudta tölteni identifikációs szerepét. Ezzel együtt járhatott a BAUKO (2009: 10) által meghatározó motivációnak tartott névadási hagyomány visszaszorulása, ami magyarázza, hogy az újonnan érkezettek miért nem kaptak ragadványnevet akkor sem, ha a családnevet viselő családok száma megnőtt. Ugyancsak a ragadványnévrendszer korai kialakulását és rögzült, zárt rendszerként való öröklődését támasztja alá a névadás motivációjának elhalványulása, a nevek transzparenciájának csökkenése, ami egyértelmủen jelzi, hogy a ragadványnév egyrészt mint tulajdonnév és nem mint jelző élt a névközösség tudatában, másrészt elég idő telt el létrejötte óta ahhoz, hogy a motiváció feledésbe merüljön. 
4.3.2. A ragadványnevek nyelvi jellemzői. A ragadványnevek többsége német nyelvü, méghozzá a helyi német nyelvjárást tükrözi. Használatuk kifejezetten a beszélt nyelvre korlátozódott. A továbbiakban a neveket a kiejtésük alapján, a magyar fonetikai lejegyzést követve közlöm, melléjük rendelve a standard német alakot, amennyiben ennek kikövetkeztetése lehetséges volt. Saját lejegyzésem emiatt el fog térni a korábban közölt HAPP-féle lejegyzéstől. Ennek oka, hogy HAPP a német fonetikai lejegyzés szabályait és megoldásait követte, valamint hogy anyanyelvként beszélte a lejegyzendő nyelvjárást.

4.3.3. A ragadványnevek osztályozása. Az 1947 előtti bébi ragadványnevek osztályozása csupán feltételezések alapján lehetséges. Ennek fó oka, hogy a névadás motivációja nem ismert, kikövetkeztetése pedig több szempontból is problémás. A névalakok kizárólag a beszélt nyelvben léteztek, így változandóságuk nagyobb volt. Az egykor minden bizonnyal transzparens ragadványnevek mára jelentés nélküli hangsorrá váltak anyanyelvi adatközlőim számára is. Rendszerezésük ugyanakkor így is lehetséges, hiszen a mai ragadványneveknél feltárható motivációs kategóriák támpontot jelentenek az évszázadokkal korábbi névadási szokások vizsgálatához - még akkor is, ha számolnunk kell az emberi gondolkodásmód változásával (1. N. FODOR 2010: 62). Valamint minden bizonytalanságuk ellenére is szükséges e nevek motivációs rendszerezése, hiszen így lehetséges hozzávetőleges képet kapnunk az adott közösség mindennapi életéröl, látásmódjáról. Éppen ezért a besoroláskor a nevek mellé rendeltem a valószínúsíthető közszói vagy tulajdonnévi eredetüket is, valamint a lehetséges konkrét motivációjukat. Ehhez JACOB és WILHELM GRIMM német értelmező szótárát (DWB.), valamint JoHANN CHRistoph AdELung 18. század végén kiadott felnémet tájszótárát (1793-1801) használtam. Az általam kialakított rendszer tehát a következő:

I. Családtagok nevére utaló ragadványnevek: Stefán ('István'), Fluóri (< Flórián), *Nikl (< Nikolaus 'Miklós'), Lukács, Mäte (< n. Matthias 'Mátyás').

II. Testi tulajdonságra utaló ragadványnevek:

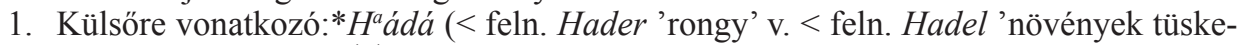
szerü termése v. egyéb része').

2. Testi hibára, járásmódra vonatkozó: *Väcsë (<n. watscheln 'biceg, kacsázik'), Täumä ( $<$ n. Taumel 'tántorgás, bukdácsolás' v. $<$ n. taumeln 'felbukik, elesik').

3. Más személyekhez vagy dolgokhoz való hasonlóság: * Käjsa (n. Kaiser 'császár').

III. Lelki tulajdonságra utaló ragadványnevek:

1. Észre, tehetségre utaló: *Läjte ( $<\mathrm{n}$. Leiter 'vezető' v. $<\mathrm{n}$. leiten 'vezet valakit').

2. Uralkodó jellemvonásra utaló: *Käjsa (n. Kaiser 'császár'), *Nikl (< n. Nickel 'kobold, gonosz manó').

IV. Életkörülményekre utaló ragadványnevek:

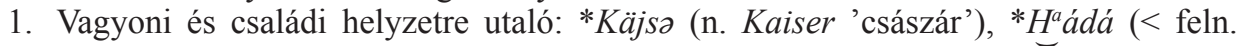
Hader 'rongy').

2. Foglalkozásra, mesterségre, tisztségre utaló: Koh (n. Koch 'szakács'), Smitt (n. Schmidt 'kovács'), *Läjte (< n. Leiter 'vezetö'), Schlossa (n. Schlosser 'lakatos'), Snäjda (n. Schneider 'szabó'), Mǟro (n. Maurer 'kőmüves'), Damen (feln. dämmen 'sároz, tapaszt v. hidat épít').

3. Egykori vagy jelenlegi lakóhelyre utaló: * Läjte (n. Leite 'lejtő').

4. Származásra, nemzetiségre utaló: Cse (n. Tscheche $\sim T$ schechisch 'cseh' v. m. cseh). 
5. Valamely eseményre utaló: *Väcsë (n. Watsche 'pofon'), * Läjte (n. Leite 'lejtö'), Tika $(<$ n. ticken 'megérint').

V. Egyéb motivációjú ragadványnevek:

1. Névasszociációs indítékú: Slégl (n. Schlegly 'sulyok' < Sulyok családnévből), *Kucsera (szl. Kucsera $\sim$ Kucsora családnévből, mely a 18. században megtalálható volt a településen).

VI. Ismeretlen motivációjú ragadványnevek: Szuháj, La $a^{o} v r e$, Szölye, Cahal, Jiahál, Pätl, Szimänd, Jänk.

4.3.4. A névállomány szemantikai-motivációs jellemzői. Annak ellenére, hogy a ragadványnevek egy részének jelentése és így a mögöttük álló motiváció is bizonytalan vagy ismeretlen, néhány jellemzőt mégis megállapíthatunk. A legbiztosabban értelmezhetők és besorolhatók a foglalkozásra utaló ragadványnevek, amelyek kétséget kizáróan alkalmasak voltak az identifikációra a névadás idejében, hiszen e mesterségek müvelőiből egy olyan kis településen, mint Béb, valószínűleg csupán egy lehetett. A névadás motivációját erösíthette az is, hogy a többségében földmüveléssel foglalkozó többi családhoz képest e személyek (családfők) legszembetűnőbb tulajdonsága a mesterségük volt. Érdemes kiemelni a Koh ragadványnevet, amelyet a leginkább megterhelt Mehringer családnevet viselő egyik család kapta. E név annak ellenére tudta betölteni identifikáló funkcióját, hogy a tényleges családnévanyagban volt Koch családnév, ám az ezt viselő családot a névközösség a Snäjdo ragadványnéven ismerte. Ez bizonyítéka annak, hogy a családi ragadványnevek valóban átvették a formális családnevek helyét a beszélt nyelvben. Az így létrejött új, kéttagú név (családi ragadványnév + keresztnév) adatközlőim nyelvhasználatában a bajor nyelvjárásban is jellemző névsorrendet követte: pl. Täumä Jozef (n. Joseph 'József'), Smitt Gy"óri (a m. György becézett Gyuri alakjának helyi nyelvjárási ejtése).

A ragadványnevek régiségének újabb bizonyítékaként említhető a Cse ragadványnév. A nevet viselő családból 1945-ben csak egyetlen élt a faluban, ezért megkülönböztetésük felesleges lett volna. Feltételezhető, hogy a korábbi időkben e család is volt olyan népes, mint a Mehringer, ezért kapott ragadványnevet, de az is lehetséges, hogy elnevezésük csupán éppen a ragadványnévadás virágkorára esett. Mindenesetre úgy vélem, nem alaptalan a névnek a HAPP (1915: 84-85) által gyüjtött adatokkal való összevetése: pẹ̄m Jōži köhm

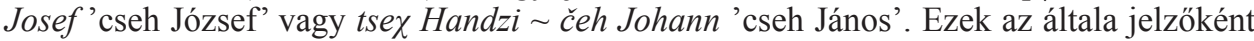
feltüntetett, ám véleményen szerint valójában (családi) ragadványnévként funkcionáló elnevezések arra utalnak, hogy a 18. században érkezett telepesek valóban cseh területről, illetőleg ahhoz közel eső területekről is érkezhettek, így mikor a ragadványnevet megkapta a család, származásuk még minden bizonnyal ismert volt.

\subsection{A ragadványnevek rendszere 1947-től napjainkig}

4.4.1. A ragadványnevek funkciója. A német származású lakosság kitelepítése, kiköltöztetése és viszonylag hamar lezajlott nyelvcseréje következtében a korábbi családi ragadványnévrendszer majdhogynem eltünt. Egyes, az 1950-1960-as években született adatközlöim ismerték még a Nikl, Szuháj, Flư ri, Mäaro, Käjsə, Tika neveket, ám ezek nem családi ragadványnévként éltek tudatukban, hanem egy-egy idősebb lakos ragadványneveként, amelyet nem örökítettek át a következő generációra. Nyomaikat azonban még megtaláljuk a 20. század második felében létrejött ragadványnévrendszer egyes olyan 
elemeiben is, mint a Tikesztár Szívlapát. E név motivációját az jelentette, hogy az elnevezettet a szénrakodásnál a Tika családi ragadványnevet viselő idősebb úr lapáttal szájon találta. A Petlel a Pätl családi ragadványnév és a vélhetően 'néni' jelentésủ feln. äl közszó összevonásával keletkezett: a Pätl äl szerkezettel utaltak ugyanis a német anyanyelvüek az egyik idősebb lakosra, a magyar anyanyelvü fiatalabb generáció számára azonban a szerkezet csupán értelmetlen hangsor volt.

A korábbi ragadványnevek eltủnése nem hozta magával a pótlás igényét. Ebben közrejátszhatott a névadási gyakorlat már említett kifulladása, valamint a családnevek megterheltségének látványos csökkenése. 1999-re a lakosság csaknem a felére csökkent, így 254 főre 64 különböző családnév jutott. Szerepe volt ebben az önkéntes és kényszerített elvándorlásnak, így bizonyos családnevek eltünésének, valamint a betelepülö magyar és cigány családoknak és az általuk hozott családneveknek is. Emellett szintén közrejátszott benne a keresztnévanyag bővülése. Így az 1947 után keletkezett ragadványnevek elsődleges célja már nem a megkülönböztetés, hanem a jellemzés: az elnevezettnek a külső-belső tulajdonságai, szokásai vagy a vele kapcsolatos események alapján való identifikációja. Ennélfogva e nevek már nem a teljes névközösség számára ismertek és használatosak, hanem csoportokhoz, kisebb társaságokhoz vagy akár generációkhoz kötődnek.

Szerkezetileg a ragadványnév jellemzően helyettesíti a formális nevet, ritkábban a családnév helyettesítőjeként szerepel a keresztnévvel együtt. Ez utóbbinak azonban mindig van valamilyen szemantikai funkciója: ilyen a Tamás Tamás ragadványnév, amelynek játékos hatását a ragadványnév mögött álló motiváció (a névviselő tamáskodó természete) és az eleve viselt keresztnévnek a ragadványnévvel való azonossága adja.

4.4.2. A ragadványnevek nyelvi jellemzői. A ragadványnevek elsődlegesen a beszélt nyelvben voltak és vannak használatban. Fontos idézni itt BAuKónak (2009: 79) a kétnyelvü környezet ragadványnév-használatára vonatkozó megállapítását: „A ragadványnevek állományára, nyelvi milyenségére hatással van a [...] lingvális környezet, s az egyes nyelvekből származó nevek aránya a közösség nyelvi hovatartozására is utal(hat). A település népességének nemzetiségi megoszlása befolyásolja a ragadványnevek nyelvi eredetét, általában a domináns nemzetiség nyelvéből származik a ragadványnevek döntő többsége." A 20. század második felében kialakult ragadványnevek 93,5\%-a magyar eredetü, mintegy következményeképpen a lejátszódott nyelvcserének. Meg kell jegyeznem, hogy a nyelvi besorolásnál olyan idegen eredetủ család- és keresztnévből létrejött ragadványneveket is a magyar nyelvủek közé soroltam, mint a Hitler vagy a Kenedi. Döntésem oka egyszerúen a nevek kiejtésének mikéntje volt. A névanyagban megtalálható német nyelvü ragadványnevek elsősorban a település legidősebb lakosságához, az 1920-1930-as években született generáció tagjaihoz kötődnek mind a névadót, mind a névviselöt tekintve, ugyanakkor nem lehetne generációs megoszlásról beszélni a német és a magyar nyelvü ragadványnevek használata között, ugyanis a német nyelvủek is ismertek voltak az egynyelvű lakosság egy részének körében is. Szerepel a névanyagban egy olyan ragadványnév is, amely mind magyar, mind német alakban létezett: Cukor Jancsi $\sim$ Cuka Hänzi. A német nyelvủ ragadványnevek mögött álló motiváció, esetleges közszói jelentés néhány esetben ismert volt a magyar anyanyelvủ névhasználók számára (pl. Slepn, Kācsel), néhány esetben nem (pl. Petlel). 


\subsubsection{A ragadványnevek osztályozása}

I. Testi tulajdonságra utaló ragadványnevek:

1. Külsőre vonatkozó: Ady Endre (a kigúvadt szeme miatt); Barbapapa (alacsony termetü, köpcös, mint a rajzfilmfigura); Bukszaszájú Buksza (széles, nagy szája miatt); Bügyök (alacsony termetü); Hosszi Laci (magas termetü); Hosszilábú (alacsony termetü); Reszellő (száraz, érdes bőrü); Kese (szőke hajú; használatban maradt azután is, hogy felnőtt korára bebarnult); Turcsi (az orra formájáról); Meszellö (vékony, magas termetéröl); Döme (kövér testalkatáról); Kopasz (az apja nullás géppel nyírta le a haját); Szimeringesfejü Szimem (hosszú haja a fejéhez lapult, majd lejjebb kiágazott); *Pónicsődör (alacsony termetéről), Picinyfejü (kis fejméretéröl), Pocok Poci (gömbölyded arcáról és kis szeméröl); Zsebóraszemü (a kigúvadt szeméröl); *Zsiráf Völegény (magas termetéről); Birka (bongyor hajáról); Vastagnyakú Egybenyakú (vastag nyakáról); Szörös (ápolatlan szakállat viselt); Lila (a szeme színéről); Rövidlábú (alacsony termetéről).

2. Testi hibára, járásmódra vonatkozó: Kācsel (n. 'kis kezü'); *Vak Andris (rossz volt az egyik szeme).

3. Beszédhibára vonatkozó: *Tyontyi (a legkisebb testvér pöszesége miatt).

4. Más személyekhez vagy dolgokhoz való hasonlóság: Dzsoni $\sim$ Kenedi (John F. Kennedy után); Kruscsov (Hruscsov után, a név az 1960-as években keletkezett); Tasziló (rajzfilmfigura után); Arisztid (rajzfilmfigura után); Jézus (hosszú hajú, szakállas fiatalember volt); Szándokán (a Maláj tigris c. tévésorozat alapján).

II. Lelki tulajdonságra utaló ragadványnevek:

5. Uralkodó jellemvonásra utaló: Cukor Jancsi Cukə Hänzi (n. Zukker Hansi 'Cukor Jancsi', mézes-mázas); Hāspe (n. Hase 'nyúl' , kajla természetü); Cigis Cigaretta (ódzkodott a dohányzástól, ki sem próbálta soha); *Hérfe Kakas (kakaskodó természetü); Csata (szerette a bandaháborúkat); Hāder (n., izgága, veszekedős természetü); *Pónicsődör (szoknyavadász természetéröl); Hejehuja (nagyhangú, izgága); *Tamás Tamás (tamáskodó természetéröl, a keresztneve Tamás volt); Kisehes (ha étel került elö, azonnal tolakodott az asztalhoz); Szinyor (igazi úriember volt, gyakran mondták rá: Szinyor, te egy úr vagy!); Prof (tudálékosan magyarázott); Pilátus (nagyon rossz gyerek volt); Tigris (erös ember volt, és rögtön ugrott, ha kihozták a béketürésböl); Geszler (Hermann Gessler zsarnoki karakter után a Tell Vilmos c. drámából).

6. Szólásszokásra, szavajárásra utaló: Bucsér; Tuccannyi (minden reggel ezzel a kérdéssel állított be a rokonhoz friss tejért); Bazdmeg; Nemtudjákelváltani (pénzhez jutás alkalmával a bankjegyeket lobogtatva lépett a kocsmába); *Marismencs (< a Maris becenévböl és a n. mentsch 'ember' közszó összevonásából, folyton így emlegették öt az idősebbek); *Petlel (< a Pätl családi ragadványnévből és a n. äl 'néni' közszó összevonásából, az idősek így emlegették az illetőt).

7. Megszokott, kedvelt cselekvésre utaló: Hitler (náci karlendítés használata mint üdvözlésforma); Slepn (n. schleppen 'vontat', folyton a barátja motorján csimpaszkodva közlekedett); Memme (négyóránként hazament enni; a szó az étel helyi dajkanyelvi megfelelője).

8. Kedves ételre utaló: Tutti (szerette a Tutti-Frutti nevü édességet).

III. Életkörülményekre utaló ragadványnevek:

9. Vagyoni és családi helyzetre utaló: *Csarnokos Öcsi (ő volt a fiatalabbik testvér), *Zsiráf Völegény (a névviselö agglegény). 
10. Foglalkozásra, mesterségre, tisztségre utaló: *Csarnokos Öcsi $\sim$ Csarnokos Gyula (a szülei vezették a tejcsarnokot); Meki (egy időben kecskét tartott); Tikos (anyja csibéket tenyésztett).

11. Valamely eseményre utaló: Gugujle (egy platós autón utazott hátul állva, a vezetőfülkéből hátrakiáltottak neki egy lelógó faág miatt: „Guggolj le!”, azonban ő úgy értette: „Ugorj le!”, és le is ugrott, súlyos sérüléseket szerezve); Szívlapát *Tikesztár Szivlapát (a rakodásnál egy Tika ragadványnevet viselő úr szívlapáttal szájon találta); *Gerecs $\sim{ }^{*}$ Göröcsgerecs (egy alkalommal nagyon jól futballozott); Kruci (A krucifixedet neked, maradj már nyugton! latinos káromkodásból, a névviselő nagyon fegyelmezetlen volt).

IV. Egyéb motivációjú ragadványnevek:

12. Névasszociációs indítékú: *Tikesztár Szívlapát (a Tikə ragadványnévböl is); Kakas (< a Kokas családnévböl); Stiglic (< a Stenger családnévböl); *Hérfe Kakas (< a Fehér családnévböl); Csimasz (< a Dzsimi ragadványnévből); Cubi (< a Czubelák családnévböl); *Gerecs *Göröcsgerecs (< a Göröcs családnevü válogatott futballistáról); Dzsoni (< a János keresztnévből); Bubu (< a Brunner családnévből); Maszka (< a Masszi családnévböl); Fenyő (< a Fenyvesi családnévből); *Csitur (< a Turcsi ragadványnévböl); Börci (< a Berci becenévből); Tilacs (< a Tihamér keresztnévből, az apja keresztneve után); Nejlon (< a Veinland családnévből); Maci Laci (< a Masszi családnévböl); Hamis (< a Hammer családnévből); *Marismencs (< a Maris keresztnév és a n. mentsch 'ember' közszó összevonásából); *Petlel (< a Pätl családi ragadványnévből és a n. äl 'néni' közszó összevonásából).

13. Puszta identifikációs és érzelmi indítékú: *Tyontyi (a legkisebb testvér megnevezése, aki még pöszén beszélt, a névadó a legidősebb testvér); Tatu (a névadónak tetszett a név hangzása).

V. Ismeretlen motivációjú ragadványnevek: Bogár; Bucc; Buksi; Morzsi; *Vak Andris (a keresztneve László volt); Csukszi; Lökesz; Dzsudi; Lucsa; Csicskás; Nullós; Petrolát; Derdelló; Meredek; Kara; Krüll; Pöcek; Dzsekszon.

1. ábra: Az 1945 után keletkezett ragadványnevek motiváció szerinti megoszlása

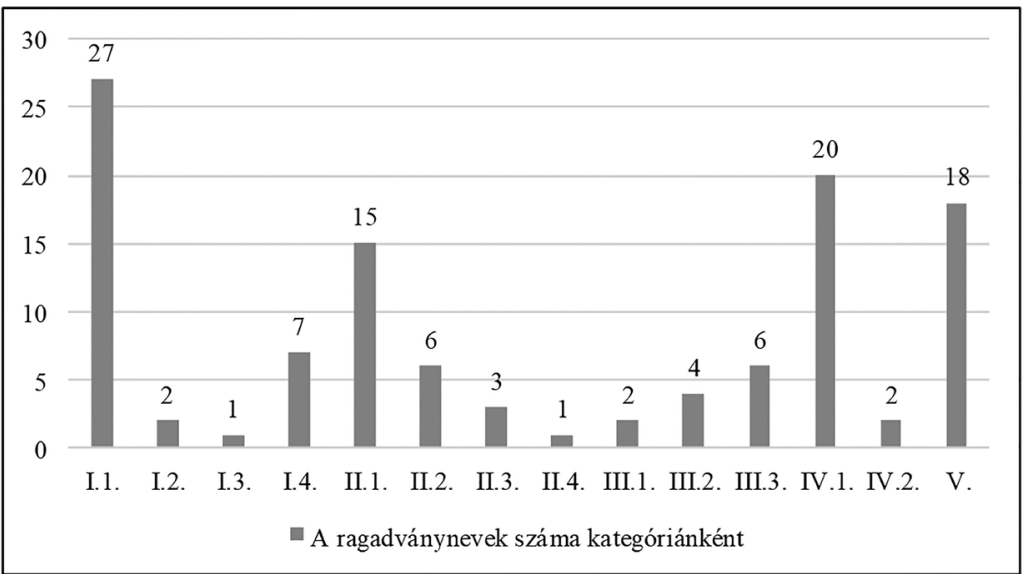


4.4.4. A névállomány szemantikai-motivációs jellemzői. Az 1. ábra az 1947 után keletkezett ragadványnevek motiváció szerinti megoszlását mutatja. Látható a külső testi tulajdonságra utaló ragadványnevek (I.1) egyértelmü többsége (a 106 névnek kb. a 25,5\%-át teszik ki), így a testi tulajdonságra utaló ragadványnevek csoportja (I.) a legnépesebb a maga 37 elemével (34,91\%). Utánuk szintén kiemelkednek a belső tulajdonságra, uralkodó jellemvonásra utaló ragadványnevek (II: 23,59\%). Ez azt engedi sejtetni, hogy a névközösség elsősorban a látható, érzékelhető tulajdonságokat találta említésre, gúnyra vagy dicséretre méltónak, közülük is nyilván azokat, amelyek kirívóak, eltérnek a tipikustól. Ez összefügg a névadásban oly gyakran müködő, a prototipikalitáson alapuló kategorizációval, főként a sajátosságjelölő nevek esetében. A névadás alapjául szolgáló motiváció választása az elnevezendő entitásnak a saját kategóriája prototipikus eleméhez képest megfigyelhető különbségén és ennek a különbségnek a mértékén alapul (SLíz 2012: 286-287). A belső tulajdonságra, uralkodó jellemvonásra utaló ragadványnevek szintén a szokványostól, a társadalmilag elfogadottól, normálistól eltérő viselkedésre, cselekvésre utalnak. Ezek magas száma tehát szintén azt mutatja, hogy a névközösség a társadalom prototipikus tagjától való eltérést említésre méltónak találta, az elnevezetthez való viszonyulásuknak a kifejezése fontos volt a névadók és a névhasználók számára. Adatközlőim maguk is rámutattak, hogy e ragadványnevek keletkezésének jó része összefüggött a legfiatalabb generáció kulturális-szociális élményeivel: például a húsvéti passióval (Jézus, Pilátus), tévémüsorokkal (Szándokán, Geszler), meghatározó politikai eseményekkel (Dzsoni, Kenedi, Kruscsov). Ugyancsak fontosnak találták kifejezni a névhez való viszonyulásukat is; erre utal a névasszociációs indítékú ragadványnevek (IV.1) szintén magas száma $(18,87 \%)$. A puszta identifikációs és érzelmi indítékú ragadványnevekkel együtt pedig e nevek a névadónak és a névhasználóknak a nyelvhez, annak hangzásához, játékosságához való viszonyulását mutatják.

5. Összegzés. Béb mai és történeti ragadványnévrendszerének szerkezeti, szemantikai és nyelvi tanulságai kétségkívül rámutatnak a neveknek a társadalommal, a névhasználó közösséggel és annak történetével való szoros összefüggésére. A település 1741-1947 között nyelvileg és etnikailag homogén volt, a lakosság zárt közösségben élt, szorosabblazább kapcsolatban az öt körülvevő magyarsággal és magyarországi németséggel. Az így eltelt közel kétszáz év alatt kialakult és rögzült ragadványnévrendszer magán viselte a névközösség életének, szokásainak, családi kötöttségeinek nyomait: a német nyelvü névalakok rögzítik a település nyelvjárásának hangtani jelenségeit, a mesterségeket, amelyek megtalálhatók voltak az elsődlegesen mezőgazdasággal foglalkozó lakosság körében, és a ragadványnevek gyakorlati múködését mind az informális nyelvhasználat, mind a többségi nyelv, mind pedig a névközösség számára idegen nyelven anyakönyvezett, formális név viszonyában. E ragadványnevek utalhatnak a névközösség ragadványnévadási vitalitásának és kifulladásának hozzávetőleges idejére is.

Az 1945-1949 között elindult történeti és szociológiai folyamatok hatással voltak a település lakosságának nyelvi, etnikai viszonyaira is. A lakosság kitelepítése, más etnikumokkal való keveredése és nyelvcseréje a névrendszerben is változásokat okozott: a korábbi családi ragadványnévrendszer eltünt, helyébe egy más motivációkon alapuló, más funkciójú, más nyelvü ragadványnévrendszer lépett, amely az új felépítésü, nyelvileg és etnikailag heterogén lakosság kognitív folyamatairól ad számot. 


\section{Hivatkozott irodalom}

Adelung, Johann Christoph 1793-1801. Grammatisch-kritisches Wörterbuch der Hochdeutschen Mundart mit beständiger Vergleichung der übrigen Mundarten, besonders aber der oberdeutschen 1-4. 2. kiadás, Breitkopf, Lipcse.

BALÁzs JudiT 1982. A ragadványnevek szerepe Rábaszentandrás névrendszerében. Nyelvtudományi Értekezések 114. Akadémiai Kiadó, Budapest.

Bartha Csilla 2005. A kétnyelvüség alapkérdései. Beszélök és közösségek. Nemzeti Tankönyvkiadó, Budapest.

BAUKo JÁNos 2009. Ragadványnév-vizsgálatok kétnyelvü környezetben. Konstantin Filozófus Egyetem Közép-európai Tanulmányok Kara - Magyar Nyelvtudományi Társaság, Nyitra-Budapest.

DWB. = Deutsches Wörterbuch von Jacob Grimm und Wilhelm Grimm. Digitalisierte Fassung im Wörterbuchnetz des Trier Center for Digital Humanities, Version 01/21. https://www. woerterbuchnetz.de/DWB (2021. 02. 01.)

N. Fodor János 2010. Személynevek rendszere az ómagyar korban. A Felsö-Tisza-vidék személyneveinek nyelvi elemzése (1401-1526). Magyar Névtani Értekezések 2. ELTE BTK Magyar Nyelvtudományi és Finnugor Intézet, Budapest.

B. Gergely PirosKa 1977. A kalotaszegi magyar ragadványnevek rendszere. Kriterion Könyvkiadó, Bukarest.

Hajdú Mihály 2003. Általános és magyar névtan. Személynevek. Osiris Kiadó, Budapest.

HapP József 1915. Béb község német nyelvjárásának hangtana. In: Petz Gedeon - Bleyer JAKAB Schmidt HenRIK szerk., Német philologiai dolgozatok 8. Pfeifer Ferdinánd könyvkereskedése, Budapest.

HAuber KitTi megj. e. Személynév - nyelvhasználat - etnikum korrelációja a 17-18. századi boszorkányperekben. In: F. Bátori GyopárKa - HaVasi Zsuzsanna - Korompay EszTer szerk., Anyanyelvünk évszázadai 5-6. ELTE Magyar Nyelvtörténeti, Szociolingvisztikai, Dialektológiai Tanszék, Budapest. Megjelenés elött.

HofFMAnN István 2012. Funkcionális nyelvészet és helynévkutatás. Magyar Nyelvjárások 50: 9-26.

KnIPf-Komlósi Erzsébet 2011. Wandel im Wortschatz der Minderheitensprache: Am Beispiel des Deutschen in Ungarn. Zeitschrift für Dialektologie und Linguistik, Beihefte 145. Franz Steiner Verlag, Stuttgart.

LÁszló PÉTer 2002. Béb. Béb Község Önkormányzata, Pápa.

LöRINCZE LAJOs 1951. Szempontok és adatok személyneveink újkori történetéhez. Magyar Nyelvjárások 1: 64-94.

MCsvA. = Magyarországi hivatalos családnév-változtatások történeti adatbázisa (1815-1932). Kutatásvezetö: FARKAS TAMÁS - KÖVESDI IsTVÁN. http://www.macse.hu/society/nevvaltoztatasok.php (2021. 02. 01.)

ÖRDÖG Ferenc 1973. Személynévvizsgálatok Göcsej és Hetés területén. Akadémiai Kiadó, Budapest.

RÁcz IstvÁn 2000. Béb község életének alakulása a II. világháború után (1945-1949). A lakosság névsora 1945- és 1999-ben. Jókai Mór Városi Könyvtár, Pápa.

SLíz Mariann 2012. Tulajdonnév és kategorizáció. Magyar Nyelv 108: 282-291, 400-410.

J. Soltész Katalin 1979. A tulajdonnév funkciója és jelentése. Akadémiai Kiadó, Budapest.

Szoták SzILvia szerk. 2017. Örvidéki házinevek. Imre Samu Nyelvi Intézet Kiadványai 6. UMIZ Imre Samu Nyelvi Intézet, Alsóőr. 
Tóth KataLin 1966. A Karancs vidéki ragadványnévadás kérdéseihez. Magyar Nyelvjárások 12: 95-107.

Urb. = Mária Terézia Úrbéri Tabellák. https://archives.hungaricana.hu/hu/urberi/ (2020. 11. 15.)

Hauber KitTi

ORCID: https://orcid.org/0000-0002-3616-7983

ELTE Eötvös Loránd Tudományegyetem

Bölcsészettudományi Kar

\section{Kitti HAUber, The bilingual nickname stock of Béb}

The paper deals with the questions regarding the nature and functions of nicknames in language use and presents the former and current nickname stock of Béb, a small village in the Transdanubian area of Hungary as indicators of the strong correlation between names, a community and its history. For two centuries the rich, heritable German nicknames represented the family relations and the cultural and dialectical features of the ethnically and linguistically homogeneous population of Béb. However, the direct consequences of World War II launched the unstoppable process of ethnic mixing and language change, which had an impact on the nickname stock as well: the former nickname stock began to fade with the oldest generations and was replaced with a new, bilingual nickname stock. The structural, semantic and lingual aspects of the nicknames used by a mostly monolingual younger generation can provide information about the cognitive processes which played a significant role in their creation. 